\title{
HUBUNGAN SELF ASSESMENT SYSTEM DENGAN TINGKAT KEPATUHAN WAJIB PAJAK PADA KANTOR PELAYANAN PAJAK PRATAMA ARGAMAKMUR PROVINSI BENGKULU
}

\author{
Karona Cahya Susena, Suwarni, Joko Widianto \\ Program Studi Manajemen Fakultas Ekonomi Universitas Dehasen Bengkulu \\ karona_cs@yahoo.co.uk
}

\begin{abstract}
ABSTRAK
Karona Cahya Susena, Suwarni, Joko Widianto; Tujuan penelitian ini adalah untuk mengetahui hubungan pemungutan pajak dengan self assesment system dengan tingkat kepatuhan wajib pajak di Kantor Pelayanan Pajak Pratama Argamakmur Provinsi Bengkulu. Metode analisis yang digunakan adalah Distribusi Rata-rata, Korelasi Spearman Rank dan Uji hipotesis. Berdasarkan hasil analisis yang telah dilakukan maka diketahui bahwa nilai rho (hitung) $\boldsymbol{\rho}$ adalah 0,755 berada pada interval interprestasi korelasi 0,600-0,799, tingkat hubungan yang kuat. Artinya hubungan self assesment system dengan tingkat kepatuhan wajib pajak pada Kantor pelayanan pajak pratama Argamakmur Provinsi Bengkulu adalah kuat dan nilai rho (hitung) sebesar 0,755 > 0,364 rho (tabel) sehingga Ho ditolak dan Ha diterima, artinya ada hubungan yang signifikan antara self assesment system dengan tingkat kepatuhan wajib pajak pada Kantor Pelayanan Pajak Pratama Argamakmur Provinsi Bengkulu.
\end{abstract}

ABSTRACT

Karona Cahya Susena, Suwarni, Joko Widianto; The purpose of this study was to determine the relationship of tax collection with the self assessment system with the level of taxpayer compliance in the Kantor Pelayanan Pajak Pratama Argamakmur Provinsi Bengkulu. The analytical methods used are Average Distribution, Spearman Rank Correlation and Hypothesis Testing. Based on the results of the analysis that has been done, it is known that the value of rho (count) $\boldsymbol{\rho}$ is 0.755 in the interval of interpretation of the correlation of 0.600-0.799, a strong level of relationship. This means that the relationship between the self assessment system and the level of tax compliance at the Kantor Pelayanan Pajak Pratama Argamakmur Provinsi Bengkulu is strong and the value of rho (count) is $0.755>0.364$ rho (table) so that Ho is rejected and $\mathrm{Ha}$ is accepted, meaning that there is a significant relationship between the self assessment system with taxpayer compliance level at the Kantor Pelayanan Pajak Pratama Argamakmur Provinsi Bengkulu.

Key Words: Self Assesment System, Tingkat Kepatuhan Wajib Pajak.

\section{LATAR BELAKANG}

Negara Indonesia dengan tujuan pembangunan nasional diperlukan investasi dalam jumlah besar yang pelaksanaannya harus berlandaskan pada kemampuan sendiri. Oleh karena itu perlu diletakkan suatu landasan yang dapat menjamin tersedianya dana dari sumber-sumber di dalam negeri guna melepaskan diri dari ketergantungan pada sumber luar negeri sehingga bantuan luar negeri hanya merupakan pelengkap yang makin lama makin kecil peranannya, salah satu sumber dana dari dalam negeri adalah pajak. Dilihat dari segi ekonomi, pajak adalah sumber penerimaan negara paling potensial.

Masyarakat yang mandiri dan peduli diharapkan mempunyai kesadaran yang tinggi dalam melaksanakan kewajiban sebagai warga negara untuk membantu bangsanya dalam mewujudkan tujuan mulia. Direktorat Jenderal Pajak sebagai pengayom perpajakan di Indonesia dengan programprogramnya sudah berusaha untuk menekan sekecil mungkin tunggakan pajak. Pelayanan yang lebih baik, pembinaan, penyuluhan, sosialisasi, pengawasan, bahkan sanksi-sanksi perpajakan telah diterapkan guna meminimalisasi tunggakan pajak dan diharapkan wajib pajak lebih patuh. Tetapi pada kenyataannya masih saja ada penyimpangan yang dilakukan wajib pajak untuk menghindari kewajiban perpajakannya. Adanya penyimpangan berupa pelanggaran yang dilakukan wajib pajak tersebut itulah yang menyebabkan tunggakan pajak terus meningkat. Oleh karenanya harus dilakukan tindakan pemungutan pajak yang mempunyai kekuatan hukum memaksa.

Pemungutan pajak merupakan suatu bentuk kewajiban warga Negara selaku Wajib Pajak serta peran aktif untuk membiayai berbagai keperluan Negara yaitu berupa pembangunan nasional yang pelaksanaannya diatur dalam undang-undang dan peraturan untuk tujuan kesejahteraan bangsa dan Negara. Untuk menjalankan pemerintahan dan pembangunan pemerintah membutuhkan dana yang tidak sedikit. Dana tersebut dari berbagai sumber penghasilan antara lain kekayaan alam, barang-barang yang dikuasai oleh pemerintah, denda-denda, atau warisan yang diberikan kepada Negara, hibah, wasiat, dan 
iuran masyarakat kepada Negara berdasarkan undang-undang (dipaksakan) dengan tidak mendapat jasa timbal. Perencanaan pajak juga dapat berkonotasi positif yaitu sebagai perencanaan pemenuhan kewajiban perpajakan secara lengkap, benar, dan tepat waktu sehingga dapat menghindari pemborosan sumber daya secara optimal.

Dalam pelaksanaannya terdapat perbedaan kepentingan antara pemerintah dan Wajib Pajak. Wajib Pajak berusaha untuk membayar pajak sekecil mungkin, karena dengan membayar pajak berarti mengurangi kemampuan Wajib Pajak. Dilain pihak pemerintah memerlukan dana untuk membiayai pengeluaran dalam rangka penyelenggaraan pemerintahan yang sebagian besar berasal dari penerimaan pajak. Adanya perbedaan kepentingan tersebut menyebabkan Wajib Pajak cenderung untuk mengurangi jumlah pembayaran pajak baik secara legal maupun ilegal. Karena untuk menjalankan pemerintahan dan pembangunan pemerintah membutuhkan dana yang tidak sedikit.

Peran serta Wajib Pajak dalam sistem pemungutan pajak sangat menentukan tercapainya rencana penerimaan pajak. Penerimaan pajak yang optimal dapat dilihat dari berimbangnya tingkat penerimaan pajak aktual dengan penerimaan pajak potensial atau tidak terjadi tax gap. Menurut James yang dikutip oleh Gunadi $(2005,4)$ menyatakan bahwa: "Besarnya tax gap mencerminkan tingkat kepatuhan membayar pajak (tax compliance)". Oleh karena itu, kepatuhan Wajib Pajak merupakan faktor utama yang mempengaruhi realisasi penerimaan pajak. Kepatuhan yang dimaksudkan merupakan istilah tingkat sampai dimana Wajib Pajak mematuhi undang-undang perpajakan dan memenuhi bidang perpajakan. Misal jika Wajib Pajak membayar dan melaporkan pajak terutangnya tepat waktu, maka Wajib Pajak dapat dianggap patuh. Self assessment system menuntut adanya peran aktif dari masyarakat dalam pemenuhan kewajiban perpajakannya. Kesadaran dan kepatuhan yang tinggi dari Wajib Pajak merupakan faktor terpenting dari pelaksanaan self assessment system, karena dengan sistem ini memungkinkan adanya potensi Wajib Pajak tidak melaksanakan kewajiban perpajakannya secara baik akibat kelalaian, kesengajaan, atau ketidakpatahuan Wajib Pajak atas kewajiban perpajakannya yang akan berdampak pada penerimaan pajak.

Sejalan dengan reformasi perpajakan (tax reform) tahun 1983 yang menghasilkan perubahan yang mendasar pada sistem dan mekanisme pemungutan pajak (dari official assessment menjadi self assessment system ), dimana dalam hal ini Wajib Pajak lah yang harus aktif dalam melaksanakan kewajiban perpajakan, mulai dari mendaftarkan diri sebagai Wajib Pajak, menghitung, memperhitungkan, membayar serta melaporkan pajaknya dengan menggunakan Surat Pemberitahuan (SPT) nya. Sistem perhitungan dan penetapan jumlah pajak terutang meliputi (1) self assessment system (wajb pajak menghitung sendiri pajaknya), (2) official assessment (wajib pajak menyampaikan informasi objek pajaknya, kemudian administrasi pajak menghitung utang pajak), (3) hybrid system (campuran antara self dan official assessment dengan berbagai kombinasinya). Informasi keuangan yang dihasilkan proses pembukuan diperlukan untuk keperluan menghitung pajak terutang dan vertiksi, serta pemeriksaan investigasi terhadap kebenaran penghitungan jumlah utang pajak itu.

Sistem self assessment memberikan kepercayaan penuh kepada Wajib Pajak, maka selayaknya diimbangi dengan adanya pengawasan yang diberikan tidak disalahgunakan. Ini menjadikan tugas Direktorat Jenderal Pajak untuk menetapkan pajak setiap Wajib Pajak menjadi berkurang. Dalam prinsip self assesment system, penentuan besarnya pajak terutang dipercayakan kepada Wajib Pajak sendiri melalui Surat Pemberitahuan (SPT) yang disampaikan. Tugas pokok Direktorat Jenderal Pajak dalam hal ini khususnya yang sangat menonjol sesuai dengan fungsinya adalah melakukan pembinaan, penelitian, pengawasan, dan pelayanan dalam hubungan dengan pelaksanaan pemenuhan kewajiban perpajakan dari Wajib Pajak, sesuai dengan ketentuan yang diatur dalam Peraturan Perundang-undangan Perpajakan yang berlaku. Fungsi Pengawasan sebagai salah satu tugas pokok Direktorat Jenderal Pajak pada dasarnya meliputi kegiatan penelitian dan pemeriksaan di bidang perpajakan. Apabila ditinjau dari segi pelaksanaannya, kegiatan - kegiatan tersebut merupakan suatu proses yang berkaitan satu sama lainnya, terutama dalam hubungannya dengan usaha penegakan Peraturan Perundang - undangan Perpajakan yang bertujuan untuk meningkatkan kepatuhan Wajib Pajak akan kewajiban perpajakannya. Perubahan sistem pemungutan pajak dari official assessment menjadi self assessment, merupakan salah satu upaya pemerintah untuk meningkatkan kemandirian dalam pembiayaan pembangunan dari penerimaan dalam negeri yang berasal dari pajak, karena penerimaan dari migas tidak dapat diandalkan lagi, sementara sumber dana dalam negeri hanya sebagai pelengkap. Sejak diterapkannya sistem self assessment dalam undang-undang perpajakan Indonesia, peranan positif Wajib Pajak dalam memenuhi seluruh kewajiban perpajakannya (tax compliance) menjadi semakin mutlak diperlukan agar sistem self assessment berjalan secara efektif, keterbukaan dan pelaksanaan penegak hukum merupakan hal yang paling penting. Penegakan hukum ini dapat dilakukan dengan adanya pemeriksaan/penyidikan pajak dan penagihan pajak. Pemeriksanaan pajak merupakan instrumen yang baik untuk meningkatkan kepatuhan Wajib Pajak, baik formal maupun material dari peraturan perpajakan, yang tujuannya untuk menguji dan 
meningkatkan kepatuhan perpajakan seorang Wajib Pajak, kepatuhan ini akan sangat berdampak baik secara langsung maupun tak langsung pada penerimaan pajak. Kepatuhan pajak dapat didefinisikan sebagai suatu keadaan dimana Wajib Pajak memenuhi semua kewajiban perpajakan dan melaksanakan hak perpajakannya (Siti Kurnia Rahayu,2010:141). Masalah kepatuhan wajib pajak adalah masalah penting diseluruh dunia baik negara maju maupun negara berkembang, karena jika wajib pajak tidak patuh akan keinginan untuk melakukan tindakan penghindaran, pengelakan, penyelundupan dan pelalaian pajak, yang ada tindakan tersebut akan menyebabkan penerimaan pajak negara akan berkurang. Kesadaran teknis dan kepatuhan memenuhi kewajiban perpajakan tidak hanya bergantung pada masalah-masalah teknis saja yang menyangkut metode pemungutan, tarif pajak, teknis pemeriksaan, penyelidikan, penerapan sanksi sebagai perwujudan pelaksanaan ketentuan peraturan perundang-undangan perpajakan, dan pelayanan kepada wajib pajak selaku pemberi dana kepada negara dalam hal membayar pajak, disamping itu tergantung kemampuan wajib pajak juga, sampai sejauh mana wajib pajak tersebut akan mematuhi peraturan perundang-undangan perpajakan (Siti Kurnia Rahayu, 2010:141)

\section{LANDASAN TEORI \\ Pajak}

Pengertian pajak dan pandangan para ahli dalam bidang tersebut memberikan berbagai definisi tentang pajak yang berbeda-beda, tetapi pada dasarnya definisi tersebut mempunyai tujuan yang sama. Untuk lebih jelasnya dan untuk memahami pengertian tentang apa yang dimaksud dengan pajak, maka dikemukakan beberapa definisi pajak sebagai berikut:

Undang - undang No.28 Tahun 2007 tentang Perubahan Ketiga atas Undang - Undang No.6 Tahun 1983 tentang Kententuan Umum dan Tata Cara Perpajakan (KUP) bahwa:

"Pajak adalah kontribusi wajib pajak kepada negara yang terutang oleh orang pribadi atau badan yang bersifat memaksa berdasarkan undang - undang dengan tidak mendapatkan imbalan secara langsung dan digunakan digunakan untuk keperluan negara bagi sebesar - besarnya kemakmuran rakyat".

Menurut Mardiasmo (2011: 1) bahwa :

"Pajak adalah iuran rakyat kepada kas negara berdasarkan undang - undang (yang dapat dipaksakan) dengan tidak mendapat jasa timbal (kontraprestasi) yang langsung dapat ditujukan dan yang digunakan untuk membayar pengeluaran umum".

Bedasarkan pengertian di atas dapat disimpulkan bahwa pajak adalah pungutan atau kontribusi wajib kepada negara yang terutang oleh orang pribadi atau badan yang bersifat memaksa berdasarkan Undang-undang, dengan tidak mendapatkan imbalan secara langsung dan digunakan untuk keperluan negara bagi sebesar-besarnya kemakmuran rakyat."

\section{Self Assessment System}

Sistem Self Assessment adalah suatu sistem yang memberikan kepercayaan dan tanggung jawab kepada Wajib Pajak untuk menghitung, memperhitungkan dan membayar sendiri jumlah pajak yang terutang sesuai dengan ketentuan perpajakan yang berlaku. Selain itu Wajib Pajak diwajibkan pula melaporkan secara teratur jumlah pajak yang terutang dan telah dibayar sebagaimana ditentukan dalam peraturan perpajakan. Pembayaran pajak selama tahun berjalan pada dasarnya merupakan angsuran pajak untuk meringankan beban Wajib Pajak pada akhir tahun pajak. Hakikat Self Assessment System adalah penetapan sendiri besarnya pajak yang terutang oleh Wajib Pajak. Pada sistem ini, masyarakat Wajib Pajak diberikan kepercayaan dan tanggung jawab yang lebih besar untunk melaksanakan kewajibannya, yaitu menghitung, memperhitungkan, membayar serta melaporkan.

Dalam sistem self assessment, administrasi perpajakan berperan aktif melaksanakan tugas-tugas pembinaan, pengawasan dan penerapan sanksi terhadap penundaan pemenuhan kewajiban perpajakan berdasarkan ketentuan yang digariskan dalam peraturan perpajakan. Fungsi pengawasan memegang peranan sangat penting dalam sistem self assessment, karena tanpa pengawasan dalam kondisi tingkat kepatuhan Wajib Pajak masih rendah, mengakibatkan sistem tersebut tidak akan berjalan dengan baik, sehingga Wajib Pajak pun akan melaksanakan kewajiban pajaknya dengan tidak benar dan pada akhirnya penerimaan dari sektor pajak tidak akan tercapai.

Menurut Early Sunandy (2002:95), Dalam rangka melaksanakan self assesment system ini diperlukan prasyarat yang harus dipenuhi untuk menunjang keberhasilan dari pelaksanaan sistem pemungutan ini yaitu:

1) Kesadaran wajib pajak (Tax consciousnessi) 
Kesadaran wajib pajak artinya wajib pajak mau dengan sendirinya melakukan kewajiban perpajakannya seperti mendaftarkan diri, menghitung, membayar, dan melaporkan jumlah pajak terutangnya.

2) Kejujuran wajib pajak

Kejujuran wajib pajak artinya wajib pajak melakukan kewajibannya dengan sebenar-benarnya tanpa adanya manipulasi, hal ini dibutuhkan dalam karena fiskus memberi kepercayaan kepada wajib pajak untuk mendaftarkan diri, menghitung, membayar dan melaporkan sendiri jumlah pajak yang terutang.

3) Kemauan membayar pajak dari wajib pajak (Tax Mindedness) Tax Mindedness artinya wajib pajak selain memiliki kesadaran akan kewajiban perpajakannya, namun juga dalam dirinya terdapat hasrat dan keinginan yang tinggi dalam membayar pajak terutangnya.

4) Kedisiplinan wajib pajak (Tax Disicipline)

Kedisiplinan wajib pajak artinya wajib pajak dalam melakukan kewajiban perpajakannya dilakukan dengan tepat waktu sesuai dengan ketentuan dan peraturan yang berlaku.

\section{Kepatuhan}

Adanya sanksi administrasi maupun sanksi hukum pidana bagi Wajib Pajak yang tidak memenuhi kewajiban perpajakannya dilakukan supaya masyarakat selaku Wajib Pajak mau memenuhi kewajibannya.Hal ini terkait dengan ikhwal kepatuhan perpajakan atau tax compliance. Kepatuhan adalah ketaatan atau berdisiplin, dalam hal ini kepatuhan pajak diartikan secara bebas adalah ketaatan dalam menjalankan semua peraturan perpajakan. Menurut Nurmantu (2003:148). Kepatuhan pajak dapat didefinisikan sebagai suatu keadaan Wajib Pajak memenuhi semua kewajiban perpajakan dan melaksanakan hak perpajakannya. Kepatuhan juga perilaku yang taat hukum.Secara konsep, kepatuhan diartikan dengan adanya usaha dalam mematuhi peraturan hukum oleh seseorang atau organisasi.

Dalam sistem self assessment, administrasi perpajakan berperan aktif melaksanakan tugas-tugas pembinaan, pengawasan dan penerapan sanksi terhadap penundaan pemenuhan kewajiban perpajakan berdasarkan ketentuan yang digariskan dalam peraturan perpajakan. Fungsi pengawasan memegang peranan sangat penting dalam sistem self assessment, karena tanpa pengawasan dalam kondisi tingkat kepatuhan Wajib Pajak masih rendah, mengakibatkan sistem tersebut tidak akan berjalan dengan baik, sehingga Wajib Pajak pun akan melaksanakan kewajiban pajaknya dengan tidak benar dan pada akhirnya penerimaan dari sektor pajak tidak akan tercapai.

Dasar-dasar kepatuhan meliputi:

1. Indoctrination

Sebab pertama warga masyarakat mematuhi kaidah-kaidah adalah karena dia didoktrinir untuk berbuat demikian.Sejak kecil manusia telah dididik agar mematuhi kaidah-kaidah yang berlaku dalam masyarakat sebagaimana halnya dengan unsur-unsur kebudayaan lainnya.

2. Habituation

Oleh karena sejak kecil mengalami proses sosialisasi, maka lama kelamaan menjadi suatu kebiasaan untuk mematuhi kaidah-kaidah yang berlaku.

3. Utility

Pada dasarnya manusia mempunyai kecenderungan untuk hidup pantas dan teratur, akan tetapi apa yang pantas dan teratur untuk seseorang, belum tentu pantas dan teratur bagi orang lain. Karena itu diperlukan patokan tentang kepantasan dan keteraturan tersebut, patokan tadi merupakan pedoman atau takaran tentang tingkah laku dan dinamakan kaedah.Dengan demikian, maka salah satu faktor yang menyebabkan orang taat pada kaidah adalah karena kegunaan dari pada kaidah tersebut.

4. Group Identification

Dari satu sebab mengapa seseorang patuh pada kaidah adalah karena kepatuhan tersebut merupakan salah satu sarana untuk mengadakan identifikasi dengan kelompok. Seseorang mematuhi kaidahkaidah yang berlaku dalam kelompoknya bukan karena dia menganggap kelompoknya lebih dominan dari kelompok-kelompok lainnya, akan tetapi justru karena ingin mengadakan identifikasi dengan kelompoknya tadi. Bahkan kadang-kadang seseorang mematuhi kaidah kelompok lain, karena ingin mengadakan identifikasi dengan kelompok lain tersebut.

Sebenarnya masalah kepatuhan yang merupakan suatu derajat secara kualitatif dapat dibedakan dalam tiga proses, yaitu:

1. Compliance

Compliance diartikan sebagai suatu kepatuhan yang didasarkan pada harapan akan suatu imbalan dan usaha untuk menghindarkan diri dari hukuman yang mungkin dijatuhkan. Kepatuhan ini sama sekali tidak didasarkan pada suatu keyakinan pada tujuan kaidah hukum yang bersangkutan dan lebih didasarkan pada pengendalian dari pemegang kekuasaan. Sebagai akibatnya maka kepatuhan akan ada, apabila ada pengawasan yang ketat terhadap pelaksanaan kaidah-kaidah hukum tersebut. 
2. Identification

Identification terjadi apabila kepatuhan terhadap kaidah hukum ada bukan karena nilai intrinsiknya, akan tetapi agar keanggotaan kelompok tetap terjaga serta ada hubungan baik dengan mereka yang diberi wewenang untuk menerapkan kaidah-kaidah hukum tersebut. Daya tarik untuk patuh adalah keuntungan yang diperoleh dari hubungan-hubungan tersebut, sehingga kepatuhan pun tergantung pada baik buruknya interaksi tadi.

3. Internalization

Pada Internalization seseorang mematuhi kaedah-kaedah hukum oleh karena secara intrinsik kepatuhan tadi mempunyai imbalan. Isi kaidah-kaidah tersebut adalah sesuai dengan nilai-nilainya sejak semula pengaruh terjadi, atau oleh karena dia merubah pola-pola yang semula dianutnya. Hasil dari proses tersebut adalah suatu konformitas yang didasarkan pada motivasi secara intrinsik. Pusat kekuatan proses ini adalah kepercayaan orang terhadap tujuan dari kaidah-kaidah bersangkutan, terlepas dari perasaan atau nilai-nilainya terhadap kelompok atau pemegang kekuasaan maupun pengawasannya.

Berlakunya sistem self assessment di Indonesia menunjang besarnya peranan Wajib Pajak dalam menentukan besarnya penerimaan negara dari sektor pajak yang didukung oleh kepatuhan pajak (tax compliance).Dengan demikian dapat dikatakan bahwa kepatuhan pajak merupakan pelaksanaan atas kewajiban untuk menyetor dan melaporkan pajak yang terutang sesuai dengan peraturan perpajakan.Kepatuhan yang diharapkan dengan sistem self assessment adalah kepatuhan sukarela (valuntary compliance) bukan kepatuhan yang dipaksakan (compulsary compliance).Untuk meningkatkan kepatuhan sukarela dari Wajib Pajak, diperlukan keadilan dan keterbukaan dalam menerapkan perpaturan perpajakan, kesederhanaan peraturan dan prosedur perpajakan serta pelayanan yang baik dan cepat dari Wajib Pajak.

Dalam pemenuhan kewajiban perpajakan, Wajib Pajak harus mematuhi kewajibannya dalam melaksanakan kewajiban pajaknya. Kepatuhan pajak ada dua jenis yaitu:

1) Kepatuhan Formal yaitu suatu keadaan dimana Wajib Pajak memenuhi kewajiban perpajakannya secara formal sesuai dengan Undang-Undang Perpajakan.

2) Kepatuhan Material yaitu suatu keadaan dimana Wajib Pajak secara substantif hakikat memenuhi semua ketentuan material perpajakan yakni sesuai isi dan jiwa UU perpajakan.

Wajib Pajak Patuh adalah Wajib Pajak yang ditetapkan oleh Direktur Jenderal Pajak sebagai Wajib Pajak yang memenuhi kriteria tertentu yang dapat diberikan pengembalian pendahuluan kelebihan pembayaran pajak. Wajib Pajak patuh adalah mereka yang memenuhi empat kriteria dibawah ini, yakni:

1. Wajib Pajak tepat waktu dalam menyampaikan Surat Pemberitahuan (SPT) untuk semua jenis pajak dalam dua tahun terakhir.

2. Wajib Pajak tidak mempunyai tunggakan pajak untuk semua jenis pajak, kecuali telah memperoleh izin untuk mengangsur atau menunda pembayaran pajaknya.

3. Wajib Pajak tidak pernah dijatuhi hukuman karena melakukan tindak pidana di bidang perpajakan dalam waktu sepuluh tahun terakhir.

4. Laporan keuangan Wajib Pajak yang diaudit akuntan publik atau BPKP harus mendapatkan status wajar tanpa pengecualian, atau dengan pendapat wajar dengan pengecualian, sepanjang pengecualian tersebut tidak mempengaruhi laba rugi fiskal. Selanjutnya ditegaskan bahwa seandainya laporan keuangan diaudit, laporan audit tersebut harus disusun dalam bentuk panjang (long form report) dan menyajikan rekonsiliasi laba rugi komersial dan fiskal.

\section{Kerangka Analisis}

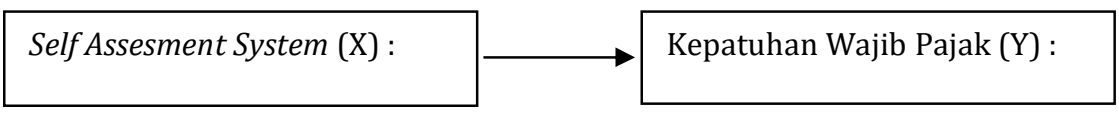

Gambar 1. Kerangka Analisis

\section{HASIL PENELITIAN DAN PEMBAHASAN \\ Hubungan Self Assesment System dengan Tingkat Kepatuhan Wajib Pajak pada Kantor Pelayanan Pajak Pratama Argamakmur Provinsi Bengkulu}

Untuk menganalisis hubungan antara self assesment system dan tingkat kepatuhan wajib pajak yang diperoleh dari jawaban responden mengenai pernyataan-perytaan yang mewakili self assesment system dengan tingkat kepatuhan wajib pajak pada Kantor Pelayanan Pajak Pratama Argamakmur Provinsi 
Bengkulu menggunakan analisis rank sperman. Data yang digunakan dalam korelasi rank sperman harus merupakan data ordinal dalam bentuk ranking yang diperoleh dari skor jawaban responden sebagaimana terlampir pada lampiran 2 - 6 . Setelah diketahui nilai $\mathrm{b}_{\mathrm{i}}^{2}$ maka dapat dihitung nilai korelasi antara kedua variabel yang di teliti.

Diketahui dari hasil perhitungan bahwa nilai $\mathrm{b}_{\mathrm{i}}{ }^{2}$ adalah 1103,5 dengan jumlah $\mathrm{n}=30$ sehingga dapat di hitung nilai koefisien korelasi rank sperman sebagai berikut :

$$
\begin{aligned}
p & =1-\frac{6 \sum b_{\mathrm{i}}{ }^{2}}{n\left(n^{2}-1\right)} \\
p & =1-\frac{6(1103,5)}{30\left(30^{2}-1\right)} \\
p & =1-\frac{6621}{30(900-1)} \\
p & =1-\frac{6621}{2.6970} \\
& =1-0,245 \\
& =0,755
\end{aligned}
$$

Dari hasil analisis korelasi rank sperman diketahui bahwa nilai $p$ (rho) hitung adalah 0,755 berada pada interval interprestasi korelasi 0,600-0,799, berarti mempunyai tingkat hubungan yang kuat. Artinya hubungan self assesment system dengan tingkat kepatuhan wajib pajak pada Kantor pelayanan Pajak Pratama Argamakmur Provinsi Bengkulu adalah kuat.

\section{Uji Hipotesis}

Untuk menentukan diterima atau ditolaknya hipotesis yang dibandingkan antara nilai rho (hitung) dengan rho (tabel), kemudian dikonsultasikan dengan kriteria pengujian hipotesisnya dengan ketentuan sebagai berikut :

1) Penentuan level of significant $95 \%$ atau alpha $(\alpha) 5 \%$

2) Ho ditolak dan Ha diterima ; jika nilai rho (hitung) > rho (tabel), artinya ada hubungan yang signifikan antara self assesment system dengan tingkat kepatuhan wajib pajak pada Kantor Pelayanan Pajak Pratama Argamakmur Provinsi Bengkulu.

3) Ho diterima dan Ha ditolak ; jika nilai rho (hitung) < rho (tabel) artinya tidak terdapat hubungan yang signifikan antara self assesment system dengan tingkat kepatuhan wajib pajak pada Kantor Pelayanan Pajak Pratama Argamakmur Provinsi Bengkulu.

Berdasarkan hasil perhitungan diperoleh nilai rho (hitung) $\rho$ sebesar 0,755 sedangkan rho (tabel) 0,364 atau 0,755 > 0,364 sehingga Ho ditolak dan Ha diterima, artinya terdapat hubungan yang signifikan antara self assesment system dengan dengan tingkat kepatuhan wajib pajak pada Kantor Pelayanan Pajak Pratama Argamakmur Provinsi Bengkulu.

\section{Pembahasan}

Berdasarkan hasil analisis yang telah dilakukan maka diketahui bahwa nilai rho (hitung) $\boldsymbol{\rho}$ adalah 0,755 berada pada interval interprestasi korelasi 0,600-0,799, tingkat hubungan yang kuat. Artinya hubungan self assesment system dengan tingkat kepatuhan wajib pajak pada Kantor pelayanan pajak pratama Argamakmur Provinsi Bengkulu adalah kuat dan nilai rho (hitung) sebesar 0,755 > 0,364 rho (tabel) sehingga Ho ditolak dan Ha diterima, artinya ada hubungan yang signifikan antara self assesment system dengan tingkat kepatuhan wajib pajak pada Kantor Pelayanan Pajak Pratama Argamakmur Provinsi Bengkulu.

Dari hasil persepsi responden mengenai self assesment system yang dilakukan oleh Kantor Pelayanan Pajak Pratama Argamakmur Provinsi Bengkulu diketahui bahwa nilai rata-rata dari seluruh jawaban responden atas seluruh pernyataan yang mewakili self assesment system adalah sebesar 4,18 berada pada interval 3,41 - 4,20 kriteria baik, dan dari tabel persepsi responden mengenai tingkat kepatuhan wajib pajak pada Kantor Pelayanan Pajak Pratama Argamakmur Provinsi Bengkulu diketahui bahwa nilai rata-rata dari seluruh jawaban responden dari pernytaan yang mewakili tingkat kepatuhan wajib pajak adalah sebesar 4,05 berada pada interval 3,41-4,20 kriteria baik.

Self assesment system merupakan komponen yang sangat penting dalam melakukan pemungutan pajak, jadi setiap kantor Pajak wajib melakukan metode pemungutan dengan menggunakan cara self 
assesment system begitupun dengan Kantor Pelayanan Pajak Pratama Argamakmur Provinsi Bengkulu untuk mengetahui seberapa besar kesadaran masyrakat untuk membayar pajak, sehingga tujuan untuk mensejahterakan rakyat bisa tercapai. Self assesment system memberikan kepercayaan penuh kepada wajib pajak untuk menghitung tunggakan pajaknya lalu kemudian melaporkan langsung ke Kantor Pajak. Apabila self assement system dapat dijalankan dengan baik oleh pemerintah maka tingkat kepatuhan wajib pajak untuk membayar pajak kepada negara khususnya pada Kantor Pelayanan Pajak Pratama Argamakmur Provinsi Bengkulu akan semakin meningkat. Berdasarkan hal tersebut maka Kantor Pelayanan Pajak Pratama Argamakmur Provinsi Bengkulu melakukan upaya untuk melakukan pemungutan dengan berbagai cara diantaranya yaiutu dengan menggunakan self assesment system guna untuk meningkatkan kontribusi masyrakat dalam membangun negara yaitu melalui sektor pajak. Negara dalam pembangunannya membutuhkan dana yang tidak sedikit, oleh karna itu sangat dibutuhkan dukungan dari seluruh rakyat dengan cara membayar pajak tepat pada waktunya, supaya dalam pembangunannya tidak terdapat kendala pada sektor dana.

Untuk menjalankan self assesment system yang baik maka Kantor Pelayanan Pajak Pratama Argamakmur provinsi Bengkulu hanya akan mengawasi wajib pajak dalam melaporkan tunggakan perpajakannya sesuai dengan undang-undang perpajakan yang berlaku, hal ini akan berhasil apabila wajib pajak telah memenuhi syarat yang telah diharapkan yaitu kesadaran wajib pajak untuk membayar pajak, kejujuran wajib pajak dalam melaporkan setiap tunggakan pajaknya, kemauan atau hasrat wajib pajak untuk membayar pajak tepat pada waktunya, serta kedisiplinan wajib pajak dalam melaporkan semua tunggakan pajaknya sesuai dengan perundang-undangan yang berlaku.

Keterkaitan self assesment sytem dengan tingkat kepatuhan wajib pajak yaitu saling berkaitan karena dengan melakukan self assesment system maka akan timbul kesadaran wajib pajak untuk membayar pajak dengan tepat waktu dan benar sehingga fiskus akan mengetahui seberapa patuh wajib pajak dalam melaporkan pajaknya. Karna kepercayaan penuh yang diberikan kepada wajib pajak maka konsekuensi yang dipikul wajib pajak juga akan semakin berat, artinya jika wajib pajak tidak memenuhi kewajiban-kewajiban perpajakan yang dibebankan kepadanya maka sanksi yang akan dijatuhkan kepadanya akan lebih berat.

Sistem ini juga dapat memberikan biaya tambahan (dalam arti luas) bagi Wajib Pajak karena Wajib Pajak akan mengorbankan lebih banyak waktu dan usaha serta biaya untuk membayar jasa konsultan pajak. Selain itu self assessment system menunjukkan proporsi yang lebih kecil dari yang telah ditetapkan sebelumnya, sehingga sesuai dengan kenyataan yang ada, jumlah pajak yang dianggarkan akan menurun pula. Di lain pihak sistem ini mempunyai beberapa keunggulan yaitu dapat meningkatkan produktifitas dan murah. Pemerintah tidak lagi dibebankan kewajiban administrasi menghitung jumlah pajak terutang Wajib Pajak dan menerbitkan Surat Ketetapan Pajak untuk memberitahukan sekaligus memerintahkan pembayaran jumlah tersebut kepada Wajib Pajak, sehingga waktu, tenaga dan biaya sehubungan dengan hal tersebut dapat dihemat atau dialihkan untuk melakukan aktivitas pemerintahan lainnya. Selain itu self assessment system akan mendorong Wajib Pajak untuk memahami dengan baik atas system perpajakan yang berlaku terhadapnya.

Dalam memutuskan untuk membayar pajak pada Kantor Pelayanan Pajak Pratama Argamakmur Provinsi Bengkulu maka wajib pajak selaku pembayar pajak akan dengan benar dan tepat melaporkan tunggakan pajak setiap bulannya untuk menghindari adanya tunggakan pajak yang berlebih pada Kantor Pelayanan Pajak Pratama Argamakmur Provinsi Bengkulu.

\section{KESIMPULAN}

1. Dari tabel persepsi responden mengenai self assesment system yang dilakukan oleh Kantor Pelayanan Pajak Pratama Argamakmur Provinsi Bengkulu diketahui bahwa nilai rata-rata dari seluruh jawaban responden atas seluruh pernyataan yang mewakili self assesment system adalah sbesar 4,18 berada pada interval 3,41 - 4,20 kriteria baik.

2. Dari tabel persepsi responden mengenai tingkat kepatuhan wajib pajak pada kantor pelayanan Pajak Pratama Argamakmur Provinsi Bengkulu diketahui bahwa nilai rata-rata dari swluruh jawaban responden atas seluruh pernyataan yang mewakili tingkat kepatuhan wajib pajak adalah sebesar 4,05 berada pada interval 3,41 - 4,20 kriteria baik.

3. Nilai rho (hitung) adalah 0,755 berada pada interval interprestasi korelasi $0,600-0,799$ tingkat hubungan yang kuat, artinya hubungan self assesment system dengan tingkat kepatuhan wajib pajak pada Kantor Pelayanan Pajak Pratama Argamakmur Provinsi Bengkulu adalah kuat.

Nilai rho (hitung) lebih besar dari rho (tabel) 0,755 > 0,364 sehingga Ho ditolak dan Ha diterima, artinya ada hubungan yang signifikan antara self assesment system dengan tingkat kepatuhan wajib pajak pada Kantor Pelayanan Pajak Pratama Argamakmur Provinsi Bengkulu. 


\section{SARAN}

Kantor Pelayanan Pajak Pratama Argamakmur Provinsi Bengkulu harus memberikan pelayanan/sosialisasi yang lebih baik kepada wajib pajak agar lebih mengerti tentang cara menghitung, mengisi SPT dan tata cara perpajakan yang baik dan benar sesuai ketentuan. Wajib pajak juga seharusnya menyadari pentingnya untuk memahami dan mengerti dalam menghitung pajak terutang serta Kantor Pelayanan Pajak Pratama Argamakmur Provinsi Bengkulu harus lebih tegas dalam mengatasi wajib pajak yang menunggak terlalu lama, agar tidak terjadi kesalahan temuan-temuan dan hal-hal yang kurang tepat dalam pencatatan administrasi perusahaan dan merugikan wajib pajak itu sendiri serta memberikan sosialiasi mengenai manfaat pemeriksaan pajak.

\section{DAFTAR PUSTAKA}

Fidel. 2010. Cara Mudah dan Praktis Memahami Masalah-Masalah Perpajakan.Jakarta : Murai Kencana Gunadi. 2005. Akuntansi pajak. Jakarata : salemba 4

Hasan, M. Iqbal, Pokok-pokok Materi Metodologi Penelitian dan Aplikasinya, Ghalia Indonesia, Bogor, 2002.

Ilyas, 2007. Perpajakan Indonesia. Jakarta : Salemba Empat

Kurnia Rahayu S.2010. Perpajakan indonesia. Jakarta : Graha baru

Mardalis. 2009. Populasi dan Sampel Penelitian.

http://triatra.wordpress.com/2011/04/05/populasi-dan-sampel-penelitian/.Diakses tanggal 25 Oktober 2017.

Mardiasmo. 2011. Perpajakan Edisi Revisi 2011. Yogyakarta : Andi Offset

Mulyadi. 2011. Akuntansi Biaya. Yogyakarya. STIE YPKPN.

Sugiyono. 2011. Metode penelitian bisnis. Bandung : Alfabeta

Sugiyono. 2010 Sistematika Untuk Penelitian. Bandung : Alfabeta

Undang-undang. No 16/2000. Tentang Pemungutan Pajak dengan Self assesmen system

Undang-undang no. 28. 2007. Tentang Ketentuan Umum dan Tata Cara Perpajakan (KUP)

Undang - undang No.28 Tahun 2007 tentang Perubahan Ketiga atas UndangUndang No.6 Tahun 1983 tentang Kententuan Umum dan Tata Cara Perpajakan (KUP) bahwa

Waluyo dan wiraman B.Ilyas. 2005. Perpajakan Indonesia. Jakarta : Salemba Empat

Waluyo. 2008. Perpajakan Indonesia.. Jakarta : Salemba Empat 